\title{
The inversion of density structure by graphic processing unit (GPU) and identification of igneous rocks in Xisha area
}

\author{
Lei Yu $\cdot$ Jian Zhang $\cdot$ Wei Lin $\cdot$ Rongqiang Wei $\cdot$ \\ Shiguo Wu
}

Received: 30 August 2013/Accepted: 25 December 2013/Published online: 31 January 2014

(C) The Seismological Society of China, Institute of Geophysics, China Earthquake Administration and Springer-Verlag Berlin Heidelberg 2014

\begin{abstract}
Organic reefs, the targets of deep-water petroleum exploration, developed widely in Xisha area. However, there are concealed igneous rocks undersea, to which organic rocks have nearly equal wave impedance. So the igneous rocks have become interference for future exploration by having similar seismic reflection characteristics. Yet, the density and magnetism of organic reefs are very different from igneous rocks. It has obvious advantages to identify organic reefs and igneous rocks by gravity and magnetic data. At first, frequency decomposition was applied to the free-air gravity anomaly in Xisha area to obtain the 2D subdivision of the gravity anomaly and magnetic anomaly in the vertical direction. Thus, the distribution of igneous rocks in the horizontal direction can be acquired according to high-frequency field, low-frequency field, and its physical properties. Then, 3D forward modeling of gravitational field was carried out to establish the density model of this area by reference to physical properties of rocks based on former researches. Furthermore, 3D inversion of gravity anomaly by genetic algorithm method of the graphic processing unit (GPU) parallel processing in Xisha target area was applied, and 3D density structure of this area was obtained. By this way, we can confine the
\end{abstract}

L. Yu $(\bowtie) \cdot$ J. Zhang $\cdot$ W. Lin $\cdot$ R. Wei

Laboratory of Computational Geodynamics, University of Chinese Academy of Science, Beijing 100049, China

e-mail: yulei110@mails.ucas.ac.cn

L. Yu $\cdot$ J. Zhang $\cdot$ W. Lin $\cdot$ R. Wei

School of the Earth Science, University of Chinese Academy of Science, Beijing 100049, China

S. Wu

Institute of Oceanology, Chinese Academy of Sciences, Qingdao 266071, China igneous rocks to the certain depth according to the density of the igneous rocks. The frequency decomposition and 3D inversion of gravity anomaly by genetic algorithm method of the GPU parallel processing proved to be a useful method for recognizing igneous rocks to its $3 \mathrm{D}$ geological position. So organic reefs and igneous rocks can be identified, which provide a prescient information for further exploration.

Keywords Xisha area - Organic reefs and igneous rocks . Frequency decomposition of potential field - 3D inversion of the graphic processing unit (GPU) parallel processing

\section{Introduction}

The northern continental margin of the South China Sea is an important area for hydrocarbon migration and accumulation (Yao 1998; Shao et al. 1999; Jin et al. 2003; Tao et al. 2005; Wan et al. 2006). Organic reefs, which have good sourcereservoir-cap combination of the configuration and favorable conditions for hydrocarbon migration developed well in Xisha area, and organic reefs in this area also have good porosity, permeability, source rock, passage for hydrocarbon migration, and high quality cover. Thus, Xisha area is an important target area for petroleum exploration (Sun et al. 2008; Yao et al. 2004; Yang et al. 2011). However, there are numerous volcanoes and igneous rocks in this area because of multistage structure evolution (Ma et al. 2009). Igneous rocks and organic reefs have similar wave impedance, appearance, and strong-amplitude reflection on the seismic sections, so it is hard to distinguish. Developing the geophysical exploration technique to identify organic reefs and igneous rocks quickly becomes an important research subject for deep-water petroleum exploration. Yet, compared with organic reefs, igneous rocks possess typical physical 


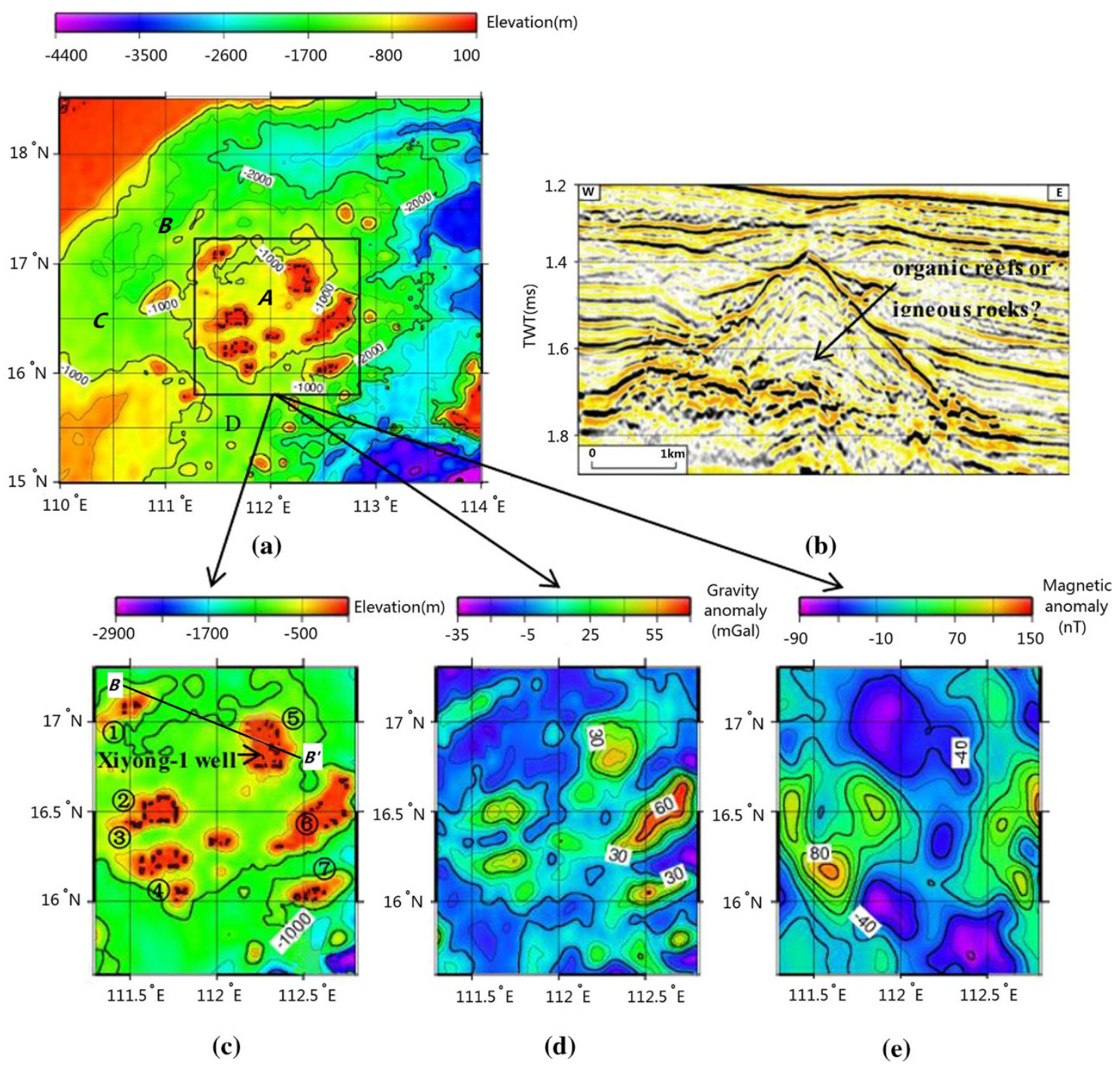

Fig. 1 The general geological and geophysical situation in Xisha area. a The geotectonic division and distribution of carbonate platform in the northern SCS; b The seismic cross-section image in the northwest of the SCS (Yang et al. 2011); c The relief map of Xisha sea area; $\mathbf{d}$ The freeair gravity anomaly in Xisha sea area; e The magnetic anomaly after reduction-to-the-pole. ( $A$ Xisha sea area, $B$ Qiongdongnan Basin, $C$ Yinggehai Basin, D Zhongjiannan Basin; Circled digit one Bei reef, Circled digit two Chenhang Island, Circled digit three Huaguang reef, Circled digit four Panshi Island, Circled digit five Yongxing Island, Circled digit six Gaojianshi, Circled digit seven Langhua reef)

properties of high density and high geomagnetic intensity (Zhang et al. 2003). It is effective to distinguish organic reefs and igneous rocks by technique of frequency decomposition and 3D inversion of the GPU parallel processing. The results can provide prescient information for further exploration.

\section{The geological and geophysical characteristics}

2.1 Distribution of organic reefs and igneous rocks in Xisha area

Xisha area is located in the southern part of Qiongdongnan Basin (Fig. 1a, b). Drilling data showed that there were
Precambrian metamorphic crystalline basements under Miocene carbonate rocks, so this area was always in continental environment before Miocene. Xisha Islands sank with the sea-floor spreading. Carbonate platform and different types of reefs began to develop since Early Miocene. Xisha apophysis was submerged during Late Miocene and formed Cretaceous strata. Organic reefs developed widely since Pliocene, and formed three big composite atolls which were named as Yongle, Xuande, and Xuandedong (Wu et al. 2009; Ma et al. 2010; Zhao et al. 2011). There are many organic reefs such as Yongxing Island, North reef, Huaguang reef, YuZhuo reef, Panshi Island, and Langhua reef growing till now (Wei et al. 2005) (Fig. 1c). 
Table 1 The statistics of rock density in the northern SCS (Hao et al. 2008)

\begin{tabular}{lllll}
\hline Era & Lithology & $\begin{array}{l}\text { Density } \\
\left(\mathrm{g} / \mathrm{cm}^{3}\right)\end{array}$ & $\begin{array}{l}\text { Mean density } \\
\left(\mathrm{g} / \mathrm{cm}^{3}\right)\end{array}$ \\
\hline Cenozoic Era & & basalt & $2.47-2.79$ & \\
Cenozoic Era & Neogene & sedimentary rock & $1.50-2.30$ & \\
& Paleogene & & $2.26-2.57$ & \\
Mesozoic Era & & sedimentary rock & $1.85-2.77$ & 2.45 \\
& & granite & $2.51-2.76$ & 2.55 \\
Paleozoic Era & Late Paleozoic & sedimentary rock & $2.34-2.79$ & \\
& Early Paleozoic & sedimentary rock & $2.52-2.80$ & 2.70 \\
Precambrian Era & metamorphic rock & $2.08-3.16$ & \\
\hline
\end{tabular}

Igneous rocks of the South China Sea mainly distribute in four areas: uplift areas of the northern continental margin, Zhongsha-Xisha uplift, Nansha area, and seamount chain of ocean basin ( $\mathrm{Li}$ et al. 2010). Igneous rocks can be divided into intrusive rocks and effusive rocks which include granites, diorites, basalts, and so on. Some granite rocks of intermediate-acidic in Xisha area extend roughly north-east and north-west along fault strike, and some distribute in the area surrounded by faults. Their shapes are controlled by deep structures and fault activities. Basicintermediate basalts are mainly caused by sea-floor spreading of the Central Basin ( $\mathrm{Li}$ et al. 2010).

\subsection{Characteristic of gravity and magnetic anomaly in Xisha area}

Gravity anomaly of Xisha area ranges from -35 to $70 \mathrm{mGal}$. The high value is located in reef islands and the maximum is in Gaojianshi Island with the value of $70 \mathrm{mGal}$. The values of other areas are generally lower and the minimum appears in the eastern researched region with the value of $-35 \mathrm{mGal}$ (Fig. 1d). Gravity anomaly is closely related to geologic bodies underground. This paper gives rock density data of the northern South China Sea according to other research results (Table 1). Geological data indicate that density difference of igneous rocks hardly changes with age. Density of intermediate-acidic igneous rocks ranges from 2.54 to $2.64 \mathrm{~g} / \mathrm{cm}^{3}$ and density of intermediate-basic igneous rocks ranges from 2.70 to $2.75 \mathrm{~g} / \mathrm{cm}^{3}$ (Li et al. 2010).

Aeromagnetic anomaly of Xisha area which extends roughly $\mathrm{E}-\mathrm{W}$ can be divided into three zones: the north part, the middle part, and the south part. Magnetic anomaly of the north part and the south part is relatively high, and the middle part is low. Since it is affected by obliquemagnetization, aeromagnetic anomaly of this area can not reflect magnetic features of geologic bodies underground. Therefore, reduction-to-the-pole at low latitude is needed. New technique for reduction-to-the-pole is used by Hao et al., and they divided magnetic inclination into 25 zones
(Hao et al. 2009). We choose $16.5^{\circ}$ as inclination and $-0.63^{\circ}$ as declination for research area, then get the result of magnetic anomaly after reduction-to-the-pole (Fig. 1e). The value of anomaly ranges from -90 to $150 \mathrm{nT}$ with the characteristic of crumby appearance. The high value is located in the eastern Gaojianshi Island, Langhua reef, Panshi Island, Huaguang reef, and Chenhang Island. The statistics of rock magnetism in the northern SCS show that sedimentary rocks and epimetamorphic rocks of Cambrian to Mesozoic are nearly nonmagnetic or weakly magnetic. High-value magnetic anomaly is mainly caused by volcanic rocks and intrusive rocks (Hu et al. 2011). The magnetic features lay the groundwork for further study of organic reefs and igneous rocks. Thus, it is possible to do further study for organic reefs and igneous rocks based on the above data (Table 2).

\section{Frequency decomposition of potential field and 3D inversion of the graphic processing unit (GPU) parallel processing}

\subsection{The research data and workflow}

The research region is called Xisha area. Its longitude ranges from $111.3^{\circ} \mathrm{E}$ to $112.8^{\circ} \mathrm{E}$ and its latitude ranges from $15.6^{\circ} \mathrm{N}$ to $17.3^{\circ} \mathrm{N}$. The researched data comes from Scripps Institution of Oceanology, University of California San Diego (http://topex.ucsd.edu/). The grid data of gravity anomaly is $1^{\prime} \times 1^{\prime}$ and the magnetic anomaly is $2^{\prime} \times 2^{\prime}$. Two kinds of technology are used in this paper, and they are frequency decomposition and 3D inversion of the graphic processing unit (GPU) parallel processing, as is shown in Fig. 2.

The procedure of frequency decomposition (1) change the gravity and magnetic anomaly from spatial domain to frequency domain by Fourier transform (Chen et al. 2008); (2) take $0.25 \mathrm{~Hz}$ as a step size to extract low-frequency field, then change the low-frequency anomaly from frequency domain to spatial domain, and extract high-frequency field at the same time; (3) select a typical section and extract its low-frequency anomaly and high-frequency anomaly; (4) analyze and contrast the result repeatedly; and (5) conjecture that there are igneous rocks underground in the area of high density and high magnetic intensity according to their physical properties of high density and high magnetic intensity.

The procedure of 3D inversion of the GPU parallel processing (1) establish 3D density model $\left(180 \times 160 \times 10 \mathrm{~km}^{3}\right)$ based on research achievement (Wang et al. 2002); (2) divide target region into 381,600 $(106 \times 90 \times 40)$ cells; $(3)$ take 0.85 as crossing-over rate and 0.08 as aberration rate and apply $3 \mathrm{D}$ inversion of gravity anomaly by genetic algorithm method of the GPU parallel processing to calculate; (3) choose 600 generations 
Table 2 The statistics of rock magnetism in the northern SCS (Hao et al. 2009)

\begin{tabular}{lllll}
\hline Lithology & Era & Name of rock & $\begin{array}{l}\text { Susceptibility } \times 10^{-5} \text { SI } \\
\text { variation range mean value }\end{array}$ & $\begin{array}{l}\text { Residual magnetization } \times 10^{-3} \mathrm{~A} / \mathrm{m} \\
\text { variation range mean value }\end{array}$ \\
\hline $\begin{array}{l}\text { Sedimentary rock } \\
\text { Metamorphic rock }\end{array}$ & $\mathrm{N}-\mathrm{Q}-\mathrm{Q} z$ & $\begin{array}{l}\text { Sandstone, mudstone, shale, conglomerate } \\
\text { Metasandstone, killas, schist, gneiss }\end{array}$ & 0 \\
& & Migmatitic paragneiss & $100-3,693$ & 0 \\
Igneous rock & $\mathrm{N}$ & Basalt & $63-8,629129$ & $630-48,7004,825$ \\
& K-J & Andesite, andesitic porphyrite & $0-24,153$ & $116-68,072$ \\
& K-J & Tuff & $0-17,953$ & $0-160,000$ \\
Intrusive rock & K-J & Rhyolite rhyolite-porphyry & $0-1,557$ & $0-11,900$ \\
& & Diorite & $314-10,1483,086$ & $226-289,600761$ \\
& Gabbro & $138-40,6944,161$ & $850-52,4002,060$ \\
\hline
\end{tabular}

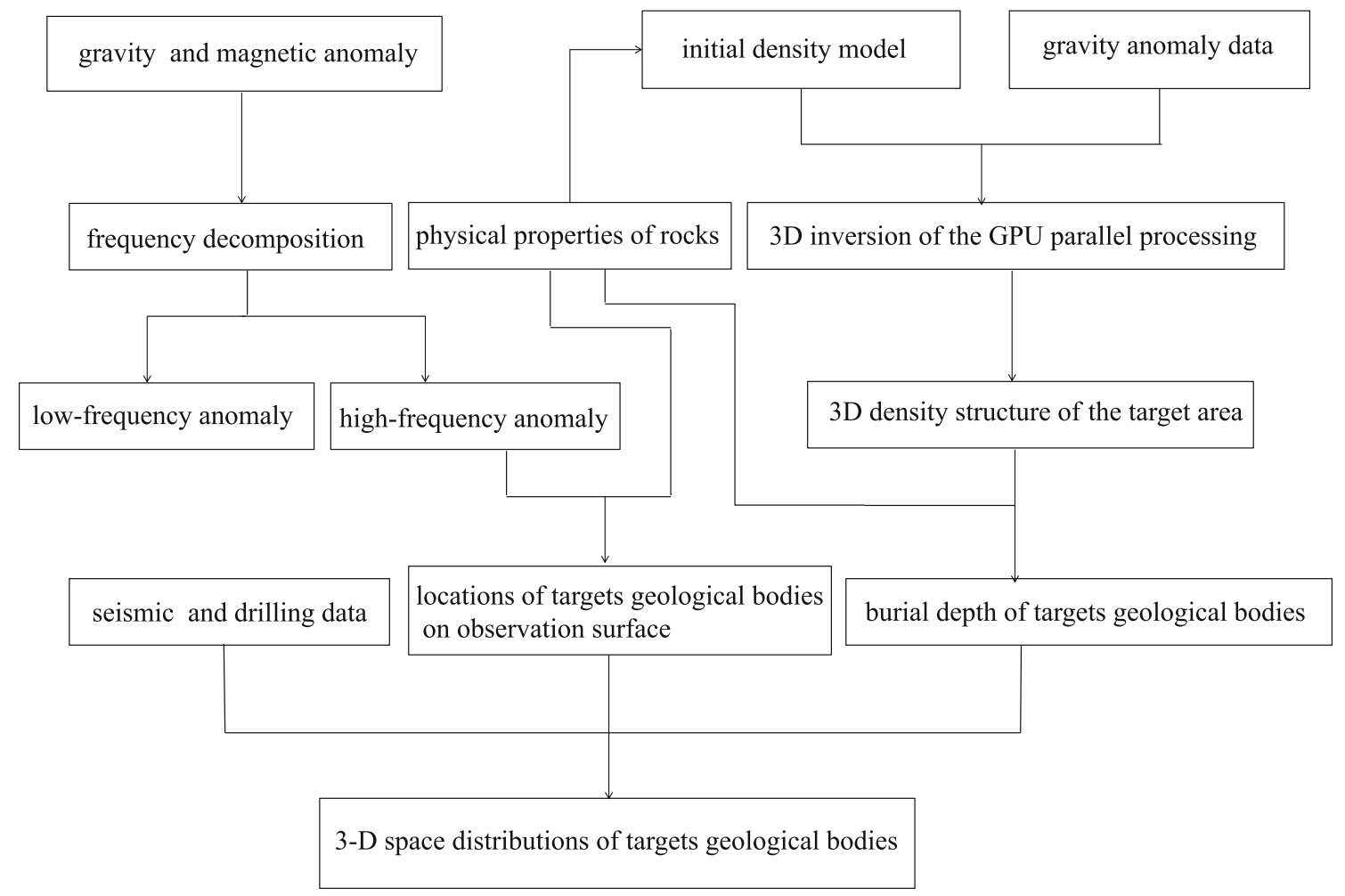

Fig. 2 The workflow of identifying organic reefs and igneous rocks by gravity and magnetic anomaly

as the final generations to invert gravity anomaly; (4) search the density of every cell by computer until density difference between observations and inverted ones approach to minimum (Lin et al. 2013 forthcoming); and (5) confine igneous rocks at a certain depth according to their density (2.54-2.64, 2.70-2.75).

We can obtain the location of igneous rocks in observation surface by frequency decomposition and confine the igneous rocks in some certain layer by genetic algorithm method of the GPU parallel processing. The two techniques realize 3D space position of the igneous rocks in the target region.

\subsection{Results analysis}

Low-frequency and high-frequency anomaly were extracted by frequency decomposition (Fig. 2), and the results were showed in Fig. 3. Figure 3a, b showed low-frequency background field and high-frequency local field of gravity anomaly separately. Figure $3 \mathrm{c}$, d showed the low- 


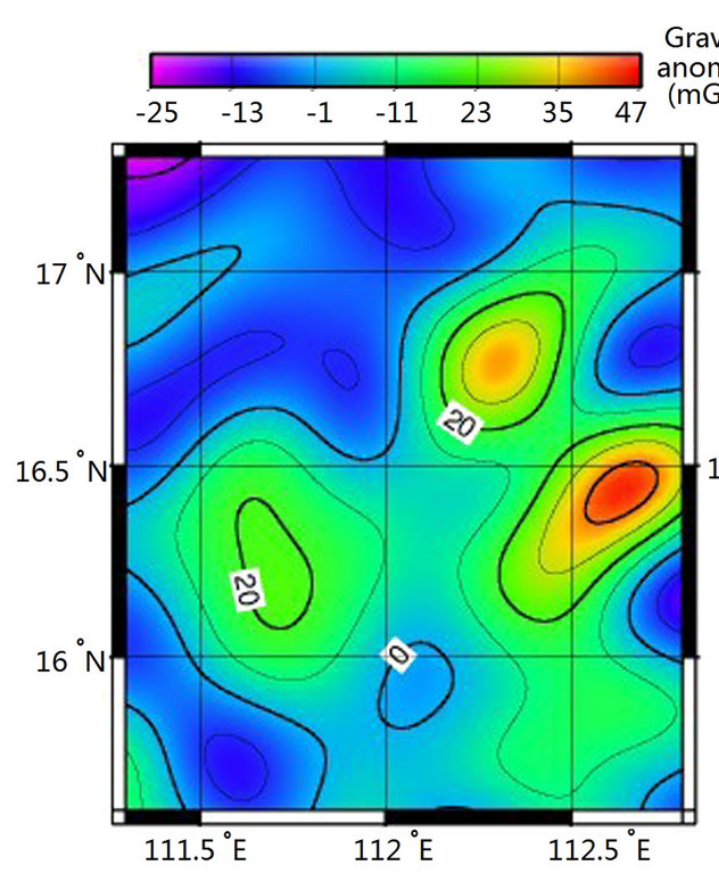

(a)
Gravity Gravity anomaly mGal)

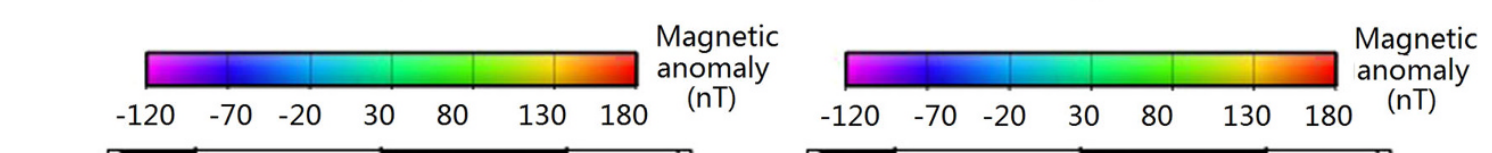

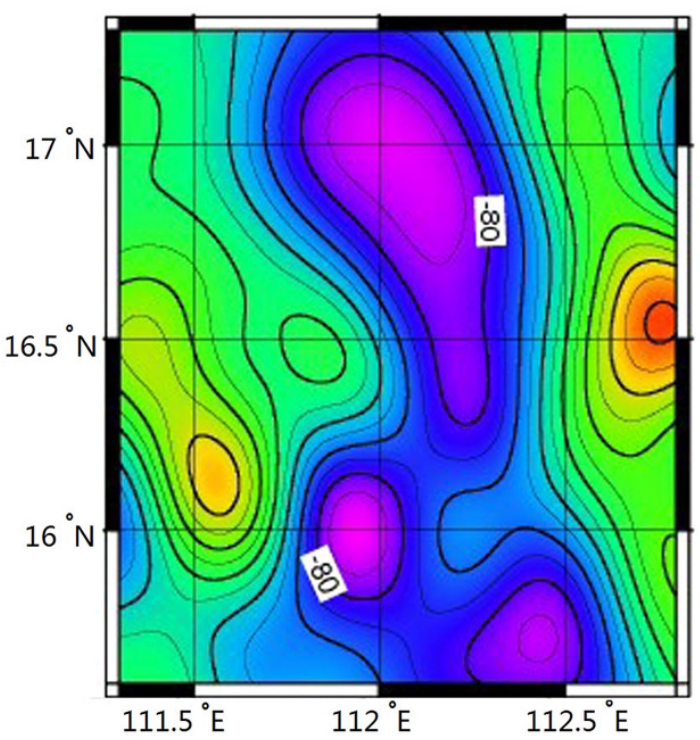

(c)

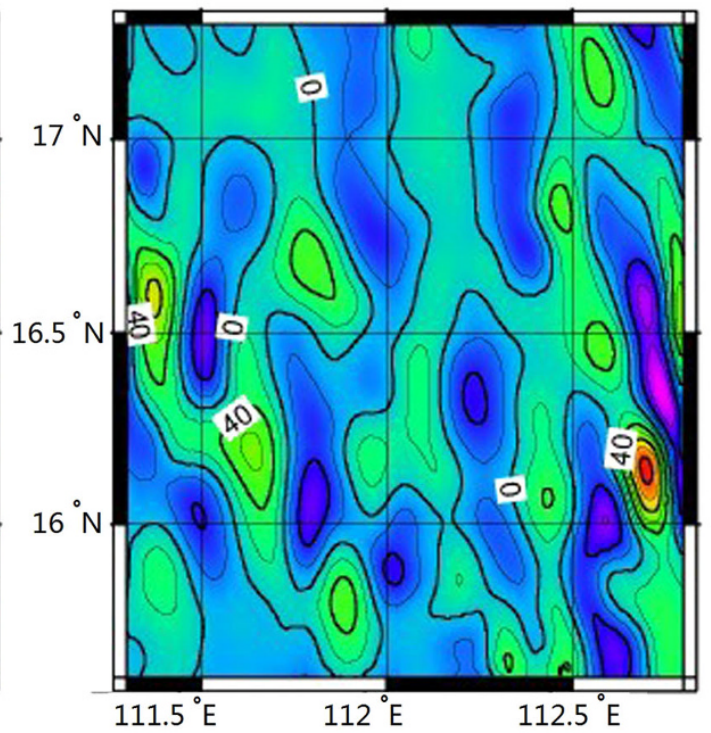

(d)

Fig. 3 The frequency decomposition a Low-frequency field of gravity anomaly; b High-frequency field of gravity anomaly; c Low-frequency field of magnetic anomaly after reduction-to-the-pole; and $\mathbf{d}$ High-frequency field of magnetic anomaly after reduction-to-the-pole

frequency background field and high-frequency local field of magnetic anomaly after reduction-to-the-pole. As shown in Fig. 3a, the high value anomaly distributed in reef islands of Yongxing Island, Gaojianshi Island and Langhua reef. Drilling data showed that there were Precambrian metamorphic basements which might cause high-value gravity anomaly. Figure $3 \mathrm{~b}$ showed that some areas of high gravity anomaly in high-frequency field concentrate in Chenhang Island, Huaguang reef, Panshi Island, eastern of Gaojianshi Island, and Langhua reef, so there seemed to have some geological bodies of high magnetic intensity underground. As shown in Fig. 3c, the magnetic anomaly was roughly along the north-south direction with a zonal distribution. The value in middle of the research region was 


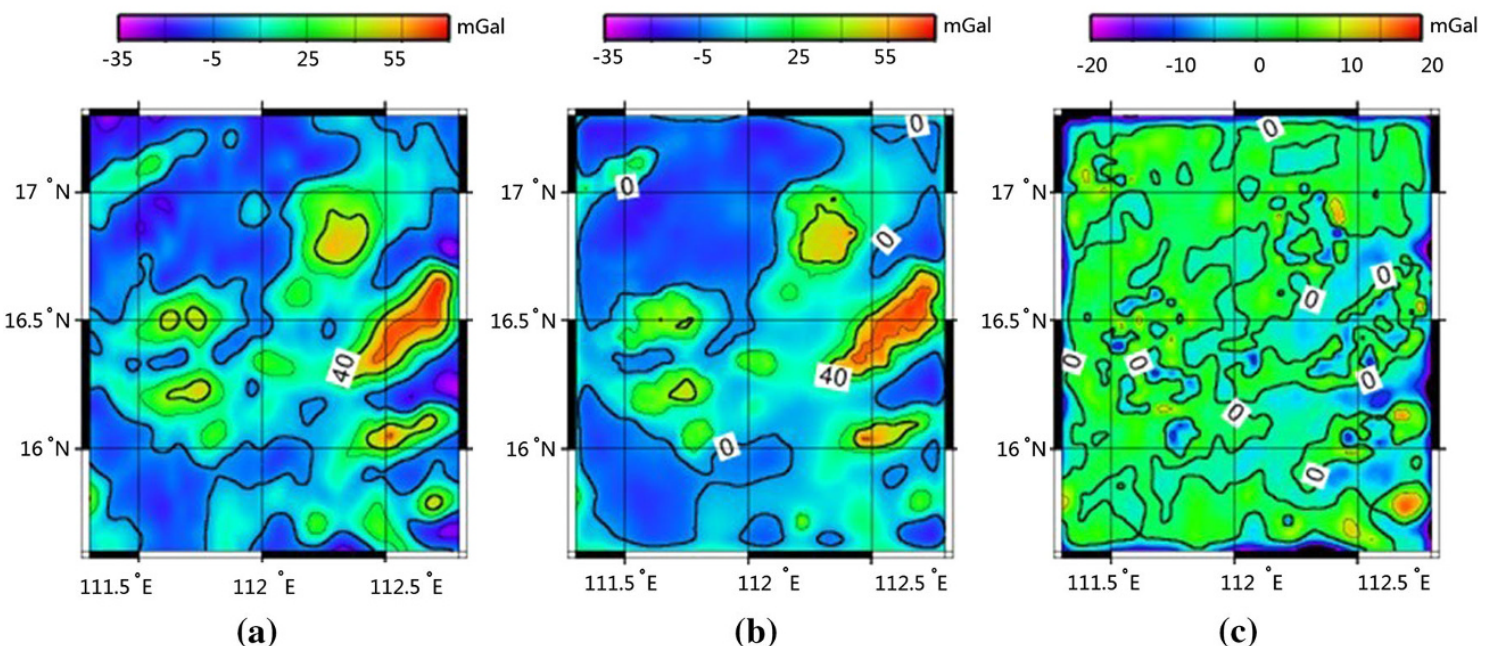

Fig. 4 Inversion results of the 3D gravity anomalies a Observations values of the free-air gravity anomaly; $\mathbf{b}$ Inversion values of the free-air gravity anomaly; c The difference between the observations values and the inversion values

low, and the lowest reached up to $-120 \mathrm{nT}$. The value of the eastern part and the western part was higher, and the highest could approach to $180 \mathrm{nT}$. This proved the existence of the magnetic basement. The magnetic basement was made up of Mesozoic intrusive rocks, volcanic rocks, and Paleozoic rocks with magnetic intensity (Hu et al. 2011). Figure $3 d$ showed that the high magnetic anomaly of highfrequency field concentrated in Langhua reef, Gaojianshi Island, Chenhang Island, Huaguang reef, and Panshi Island. And high magnetic anomaly in the western part distributed more widely than eastern part. The results of frequency decomposition showed that there were igneous rocks under Langhua reef, Gaojianshi Island, Chenhang Island, Huaguang Island, and Panshi Island. Figure 6 gave the distribution of igneous rocks in the horizontal plane.

Density difference was the foundation and precondition of gravity inversion, and we made data statistic induction and analysis in this paper to establish a reasonable structure of 3-D density model. The data indicated that there were some certain density differences between different formations of Nanhai. The density difference between Paleogene and Mesozoic, Paleogene and Mesozoic granites were $0.2-0.5 \mathrm{~g} / \mathrm{cm}^{3}, 0.3-0.5 \mathrm{~g} / \mathrm{cm}^{3}$, respectively. It had obvious density difference between sedimentary formation and basement. According to these data, we established initial density model in this paper as follows (Wang et al. 2002): seawater density was $1.03-1.04 \mathrm{~g} / \mathrm{cm}^{3}$; the density of Cenozoic sedimentary formation was $1.8-2.24 \mathrm{~g} / \mathrm{cm}^{3}$; and as the depth increased, Cenozoic sedimentary formation gradually changed to basement, and the density increased to $3 \mathrm{~g} / \mathrm{cm}^{3}$, so we set the cell density that below Cenozoic sedimentary formation increased from 2.24 to $3.2 \mathrm{~g} / \mathrm{cm}^{3}$.
We applied 3D inversion of gravity anomaly by genetic algorithm method of the GPU parallel processing to Xisha area $\left(111.3^{\circ} \mathrm{E}-112.8^{\circ} \mathrm{E}, 15.6^{\circ} \mathrm{N}-17.3^{\circ} \mathrm{N}\right)$ based on the initial density model, and the results were shown in Fig. 4. Figure $4 \mathrm{a}$ showed observations of the free-air gravity anomaly, and the values ranged from -35 to $70 \mathrm{mGal}$. We took $10 \mathrm{~km}$ as downward inversion depth and divided the target region into $106 \times 90 \times 40$ hexahedron cells, then inverted the gravity anomaly by genetic algorithm method of the GPU parallel processing after stripping away of regional field $10 \mathrm{~km}$ below. Figure $4 \mathrm{~b}$ was inverted gravity anomaly, the values, and distribution characteristics of which were similar to observations. Figure $4 c$ was the difference between observations and the inversion values. As shown in Fig. 4c, the difference in most area was less than $5 \mathrm{mGal}$ which proved the method was reliable. To see 3D density structure intuitively and clearly, we used three dimensional visualization technologies and extracted four density sections. The results were also showed in Fig. 6a. Because the inversion values were close to observations, we could select a typical section for further study in the next step.

In order to confirm that the inversion results were reliable, we chose BB' as interpretation profile. BB' profile started at the end of the seismic profile and crossed Xiyong-1 well. The seismic data and drilling data all provided reference for interpretation. Inversion results of the profile were showed in Fig. 5a, b. Figure 5a was the difference between observations and inversion values of profile BB'. We could see inversion values fit the observations well, and the BB' profile also reflected the geologic situation underground well. Figure $5 \mathrm{~b}$ was the density section of profile BB' below sea level. Drilling data of 


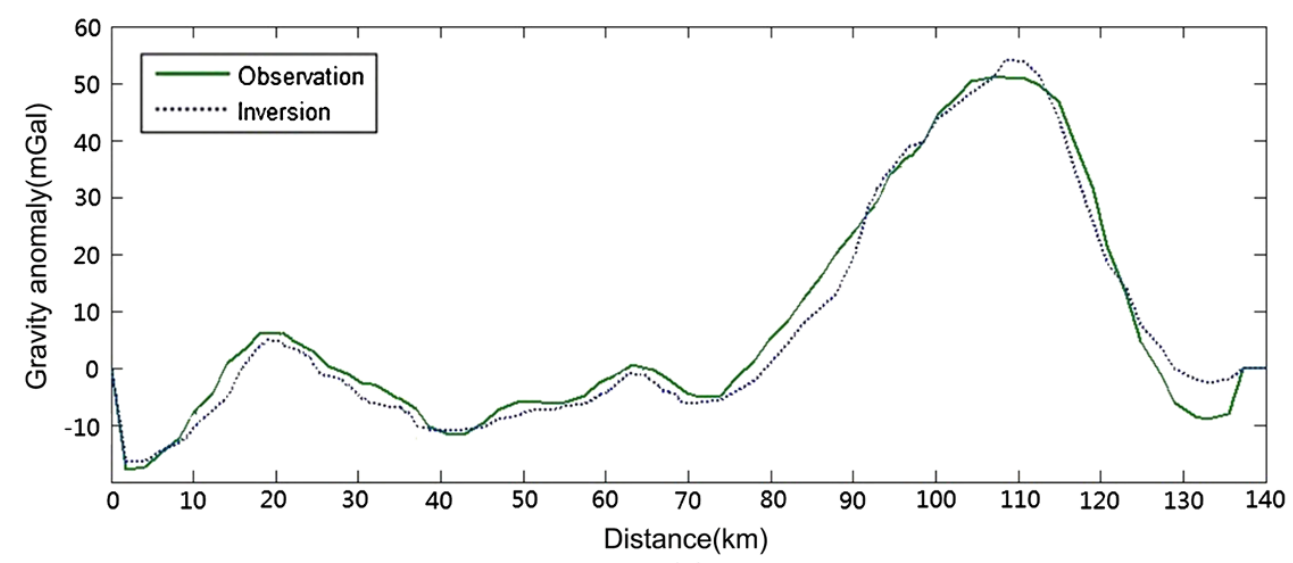

(a)

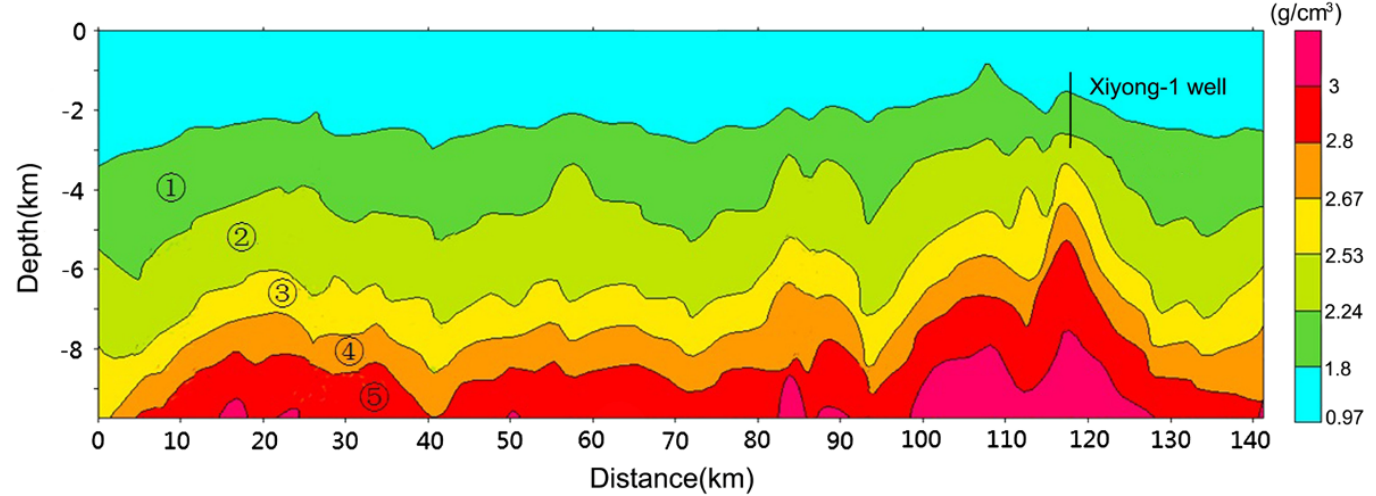

(b)

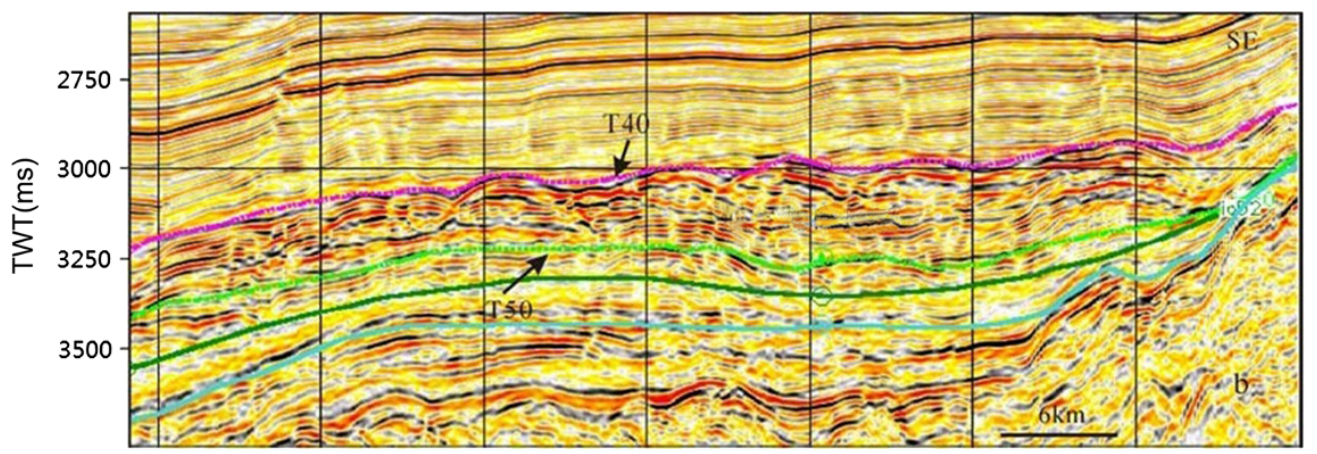

(c)

Fig. 5 Inversion results of profile BB' for contrast a The difference between the observations values and the inversion values of profile BB'; b Density section of profile BB' below sea level; c Seismic section joined with profile BB' in adjacent area

Xiyong-1 well showed that it was 1.3-km-thick Quaternary and Eogene sedimentary formation at the top, corresponding to sedimentary formation of (1) in Fig. 5b. The drilling crossed sedimentary formation of (1) and entered into the sedimentary formation of (2), demonstrating that it was thin weathering crust and mega-thick Precambrian metamorphic basement that under carbonate rocks. Sedimentary rocks and epimetamorphic rocks of Cambrian to Mesozoic of the research region were nearly nonmagnetic or weak magnetic. Magnetic anomaly of the research region was mainly caused by volcanic rocks and intrusive rocks (Hu et al. 2011). Finally, we confined igneous rocks at the layer of (3)-(4) according to the burial depth of magnetic basement and density of igneous rocks (Hao et al. 2009; Li et al. 2010). Compared with seismic profile in Fig. 5c, we draw the conclusion that the burial depth of igneous rocks in this area ranges from about 4 to $7 \mathrm{~km}$. At the same time, four density profiles were given as a reference by three dimensional visualization. The results were showed in Fig. 6. 


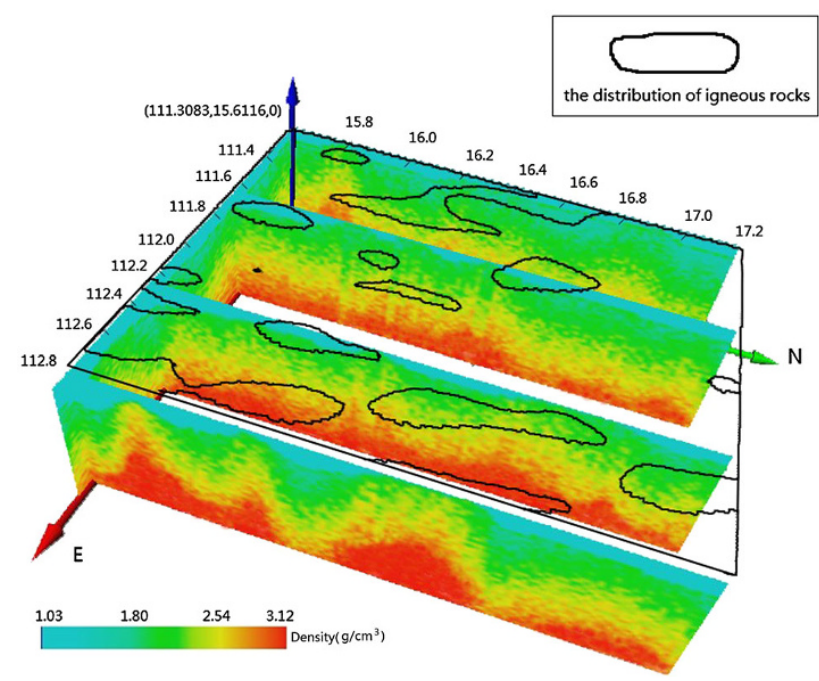

Fig. $63 \mathrm{D}$ distribution of the igneous rocks in Xisha area

\section{Conclusions}

We obtained 3D space distribution of the igneous rocks by frequency decomposition and 3D inversion of gravity anomaly by the genetic algorithm method of the GPU parallel processing. So organic reefs and igneous rocks could be identified based on this. The main conclusions of this paper were as follows:

1) We applied frequency decomposition to gravity anomaly and magnetic anomaly, and extracted lowfrequency background field and high-frequency anomaly field. In this paper, we considered that there were igneous rocks in the area of high gravity anomaly and high magnetic anomaly in the high-frequency anomaly field according to their physical properties of high density and high magnetic intensity. Thus, we obtained the distribution of the igneous rocks in the horizontal plane. The igneous rocks mainly distributed in Langhua reef, Gaojianshi Island, Chenhang Island, Huaguang Island, and Panshi Island.

2) We established initial 3D density model by former researches, and applied 3D inversion of gravity anomaly by genetic algorithm method of the GPU parallel processing to invert and calculate the density structure. The gravity anomaly between observations and the inversion values was less than $5 \mathrm{mGal}$. The results showed that using GPU parallel technology could reduce the elapsed of inversion from more than 17 days to $7 \mathrm{~h}$ in 600 generations. Thus, GPU parallel technology greatly improved the efficiency of the gravity inversion.

3) We obtained 3D space distribution of igneous rocks in Xisha area, and the inversion results showed that there were large-scale igneous rocks underground. It was inferred that the burial depth of igneous rocks in this area ranges from about 4 to $7 \mathrm{~km}$. 3D distribution of the igneous rocks can be obtained by Fig. 6 .

Acknowledgments The study is financially supported by the National Natural Science Foundation of China (No.41174085).

\section{References}

Chen S, Zhang J, Shi YL (2008) Gravity inversion using the frequency characteristics of the density distribution. Appl Geophys 5(2):99-106

Hao TY, Huang S, Xu Y, Li ZW, Xu Y, Lei SM, Yang JY (2008) Comprehensive geophysical research oil the deep structure of Northeastern South China Sea. Chin J Geophys 51(6):1785-1796 (in Chinese with English abstract)

Hao TY, Xu Y, Zhao BM, Zhang YJ, Peng LL (2009) Geophysical research on distribution features of magnetic basements in the South China Sea. Chin J Geophys 52(11):2763-2774 (in Chinese with English abstract)

Hu WJ, Jiang WW, Hao TY, Xu Y, Zhao BM (2011) Integrated geophysical research on the distribution of pre-cenozoic residual basins in the South China Sea. Chin J Geophys 54(12):3315-3324 (in Chinese with English abstract)

Jin ZJ, Yin JY, Xie FK, Lv XX (2003) Lithosphere structures and petroleum accumulation and distribution in petroliferous basin. Chin J Geol 38(3):413-424 (in Chinese with English abstract)

Li SL, Meng XH, Guo LH, Yao CL, Chen ZX, Li HQ (2010) Gravity and magnetic anomalies field characteristics in the South China Sea and its application for interpretation of igneous rocks. Appl Geophys 7(4):295-305 (in Chinese with English abstract)

Lin W, Zhang J, Li JB (2013) 3D inversion of gravity anomaly with GPU in the mesozoic residual basins of Nansha Thitu Island and Reefs Area. J Trop Oceanogr 32(4):36-42 (in Chinese with English abstract)

Ma YB, Wu SG, Zhang GC, Wang DW, Dong DD, Mi LJ (2009) Geophysical characteristics of biohermal carbonate in the northern margin deep water area of South China Sea. J China Univ Pet 33(4):33-39 (in Chinese with English abstract)

Ma YB, Wu SG, Gu MF, Lu YT, Dong DD, Zhao HT (2010) Seismic reflection characteristics and depositional model of carbonate platforms in Xisha sea area. Acta Oceanol Sin 32(4):118-128 (in Chinese with English abstract)

Shao XZ, Zhang JR, Yin XH (1999) Petroleum exploration and study on the deep crust structure. Pet Explor Develop 26(2):11-14 (in Chinese with English abstract)

Sun QL, Ma YB, Zhao Q, Qu TL, Wu SG (2008) Different reef carbonate diagenesis and its influential factors, northern South China Sea. Natural Gas Geosci 19(5):665-675 (in Chinese with English abstract)

Tao WX, Zhao ZG, He SB, Ding F (2005) Petroleum geological conditions and exploration prospects in deepwater area of Northwestern South China Sea. Acta Geosci Sin 26(4):359-364 (in Chinese with English abstract)

Wan L, Yao BC, Zeng WJ, Wu NY, Xia B, Zhu BD (2006) Lithospheric structure and petroleum distribution in the South China Sea. Geol China 33(4):874-884 (in Chinese with English abstract)

Wang JL, Zhang XB, Wu JS, Chen B, Zhong ZH, Hao HJ, Li PL, Su NR (2002) Integrated geophysical research on base texture of Zhujiang river mouth basin. J Trop Oceanogr 21(2):13-22 (in Chinese with English abstract) 
Wei X, Deng JF, Xie WY, Zhu YJ, Zhao GC, Li YX, Chen YH (2005) Constraints on biogenetic reef formation during evolution of the South China Sea and exploration potential analysis. Earth Sci Front 12(3):245-252 (in Chinese with English abstract)

Wu SG, Yuan SQ, Dong DD, Mi LJ, Zhang G C (2009) The Miocene reef development characteristics in northern South China Sea. Oceanol ET Limnol sin 40(2):117-121 (in Chinese with English abstract)

Yang TT, Lv FL, Wang B, Fan GZ, Wang X, Lu YT, Hu B (2011) Geophysical features and hydrocarbon exploration prospect of reef in Xisha offshore. Prog Geophys 26(5):1771-1778 (in Chinese with English abstract)

Yao BC (1998) Crust structure of northern margin of the South China Sea and its tectonic significance. Mar Geol Quat Geol 18(2):1-16 (in Chinese with English abstract)
Yao BC, Wan L, Liu ZH (2004) Tectonic dynamics of Cenozoic sedimentary basins and hydrocarbon resources in the South China Sea. Earth Sci-J China Univ Geosci 29(5):543-549 (in Chinese with English abstract)

Zhang SH, Liu TY, Gu HM, Deng RL (2003) The synthetic geophysics interpretation of the igneous rocks in Bayan Haote basin. Geophys Geochem Explor 27(5):383-388 (in Chinese with English abstract)

Zhao Q, Wu SG, Xu H, Sun QL, Wang B, Sun YB, Cao F, He XS (2011) Sedimentary facies and evolution of aeolianites on Shidao Island, Xisha Islands. Chin J Oceanol Limnol 29(2):398-413 